\title{
Occurrence of alien spirlin (Alburnoides sp.) in the Neretva river basin
}

\author{
Jasna Vukić ${ }^{1, *}$, Kristýna Eliášová ${ }^{2}$, Dario Marić $^{3}$ and Radek Šanda ${ }^{2}$ \\ ${ }^{1}$ Department of Ecology, Faculty of Science, Charles University, Viničná 7, Prague 2, 12844, Czech Republic \\ ${ }^{2}$ Department of Zoology, National Museum, Václavské nám. 68, Prague 1, 115 79, Czech Republic \\ ${ }^{3}$ Dobrič b.b., Široki Brijeg 88220, Bosnia and Herzegovina
}

\begin{abstract}
Northern Mediterranean region is characterised by an exceptional richness of the freshwater ichthyofauna. Many fish species of this region are endemic to a single or a few river basins. This is also the case of the Neretva river basin (Adriatic Sea slope), where 17 out of 34 native species are endemic solely to this river basin. However, these unique Mediterranean freshwater ecosystems are fragile and are susceptible to human-induced changes, including introduction of alien fish species. We report here a finding of the $32^{\text {nd }}$ alien fish species in the Neretva river basin, spirlin Alburnoides sp., which was found at two localities in Bosnia and Herzegovina. The spirlin species was identified by molecular means as so far unnamed species with the native range in the Sava river basin (Danube river basin, Black Sea slope). Based on the comparison of cytochrome $b$ sequences, the introduced population originated most probably from nearby rivers of the Danube basin in Bosnia and Herzegovina (Vrbas and Bosna river basins). Such a high number of alien fish species reported in a single river basin is alarming and pointing to a necessity of raising public awareness, especially among local fishermen.
\end{abstract}

Keywords: spirlin / Alburnoides / alien species / Neretva river / Leuciscidae

Résumé - Présence d'un spirlin non indigène (Alburnoides sp.) dans le bassin de la Neretva. La région de la Méditerranée septentrionale se caractérise par une richesse exceptionnelle de l'ichtyofaune d'eau douce. De nombreuses espèces de poissons de cette région sont endémiques à un ou plusieurs bassins hydrographiques. C'est également le cas du bassin de la Neretva (versant de la mer Adriatique), où 17 des 34 espèces indigènes sont endémiques uniquement à ce bassin. Cependant, ces écosystèmes d'eau douce méditerranéens uniques sont fragiles et sensibles aux changements induits par l'homme, y compris l'introduction d'espèces de poissons non indigène. Nous signalons ici une observation de la 32éme espèce de poisson non indigène dans le bassin de la Neretva, un spirlin Alburnoides sp. qui a été trouvé dans deux localités en Bosnie-Herzégovine. L'espèce de spirlin a été identifiée par des moyens moléculaires comme étant une espèce jusqu'à présent sans nom avec son aire de répartition indigène dans le bassin de la Sava (bassin du Danube, versant de la mer Noire). D'après la comparaison des séquences de cytochrome $b$, la population introduite provenait très probablement des rivières du bassin du Danube en Bosnie-Herzégovine (bassins des rivières Vrbas et Bosna). Un nombre aussi élevé d'espèces de poissons exotiques signalées dans un seul bassin hydrographique est alarmant et souligne la nécessité de sensibiliser le public, en particulier les pêcheurs locaux.

Mots-clés: spirlin / Alburnoides / espèce non-indigène / rivière Neretva / Leuciscidae

\section{Introduction}

Mediterranean rivers host considerable part of the European freshwater fish species. Majority of the freshwater fishes from this area are endemics, many of them occurring

\footnotetext{
${ }^{*}$ Corresponding author: jvukic@seznam.cz
}

only in a few or even a single river basin (Kottelat and Freyhof, 2007). However, at the same time, the Mediterranean rivers are strongly negatively affected by human activities, including both intentional and unintentional introductions of alien fish species (Marr et al., 2013).

The Neretva river basin (Adriatic Sea slope, Bosnia and Herzegovina and Croatia), including the endorheic karstic field drainages connected only underground with the main river, is 


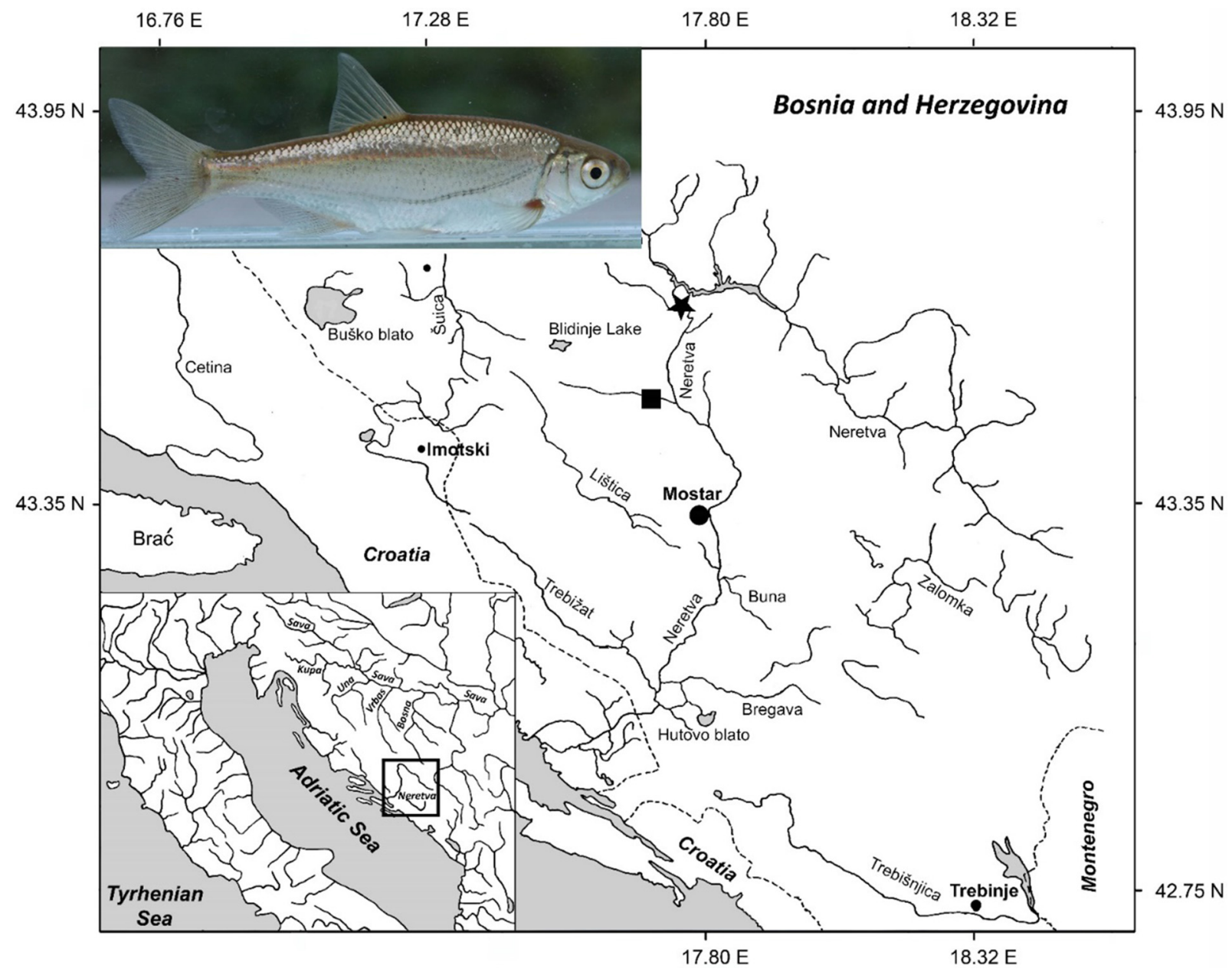

Fig. 1. Map of the Neretva river basin. Localities with Alburnoides sp. indicated: Neretva river in Jablanica ( $\star$ ) and the Drežnica river (tributary of the Neretva river) in Donja Drežnica (๘). Upper left corner: a photo of alive specimen of Alburnoides sp. from the Drežnica river.

characterised by a high degree of endemism of freshwater fishes. It is inhabited by 34 native freshwater species (Tab. S1), 17 of which are endemic solely to this basin and some of them were described only recently (Bogutskaya and Zupančič, 2003; Kovačić, 2005; Kottelat and Freyhof, 2007; Buj et al., 2010, 2014; Bogutskaya et al., 2012; Glamuzina et al., 2013; Tutman et al., 2017a). Unfortunately, also alien species have been recorded from this river basin, and their number is as high as 31 (Tab. S2) (Glamuzina et al., 2013, 2017; Dulčić et al., 2017; Tutman et al., 2017b; Sukalo et al., 2018). The majority of the introduced species are considered to have a strong negative impact on the native fishes (Glamuzina et al., 2017). Moreover, their number still increases.

The aim of this work is to provide the information on a new alien species record from the Neretva river basin, spirlin Alburnoides sp. (Leuciscidae sensu Schönhuth et al., 2018), and its probable origin, based on a molecular identification.

\section{Materials and methods}

Several specimens of Alburnoides were obtained on 4-5 October 2016, from two localities within the Neretva river basin: the Neretva river in Jablanica ( $\mathrm{N} 43^{\circ} 39^{\prime} 55^{\prime \prime}$ E $17^{\circ} 45^{\prime} 47^{\prime \prime}$ ) and the Drežnica river (a tributary of the Neretva river) in Donja Drežnica (N 43⒊ $31^{\prime} 31^{\prime \prime}$ E $\left.17^{\circ} 42^{\prime} 51^{\prime \prime}\right)$, Bosnia and Herzegovina (Fig. 1). All specimens were collected by a local sport fisherman, either by a small lift net or by fly fishing. The specimens were sacrificed by over-anaesthetisation by quinaldine. A piece of fin tissue was stored in $96 \%$ ethanol for subsequent molecular analyses. The voucher specimens were preserved in $4 \%$ solution of formaldehyde immediately after the collection, and later transferred to $70 \%$ ethanol and stored in the ichthyological collection of the National Museum in Prague (collection numbers NMP P6V 144776-144793). Since the taxonomy of Alburnoides in Europe, and especially in the Balkans, is still unresolved, i.e. the genus includes cryptic species (Stierandová et al., 2016), and morphological data enabling identification are missing for many species/ populations, we used molecular data for identification.

The DNA extraction, PCR reactions, amplification protocol and PCR product purification follow Šanda et al. (2008a). Sequencing was carried out by the Macrogen Service Centre Europe (Amsterdam, Netherlands) using the internal primers from Stierandová et al. (2016).

The sequences were aligned manually and revised in Geneious R9.1. The final alignment included 1140 base pairs of cytochrome $b$. Previously published sequences of 


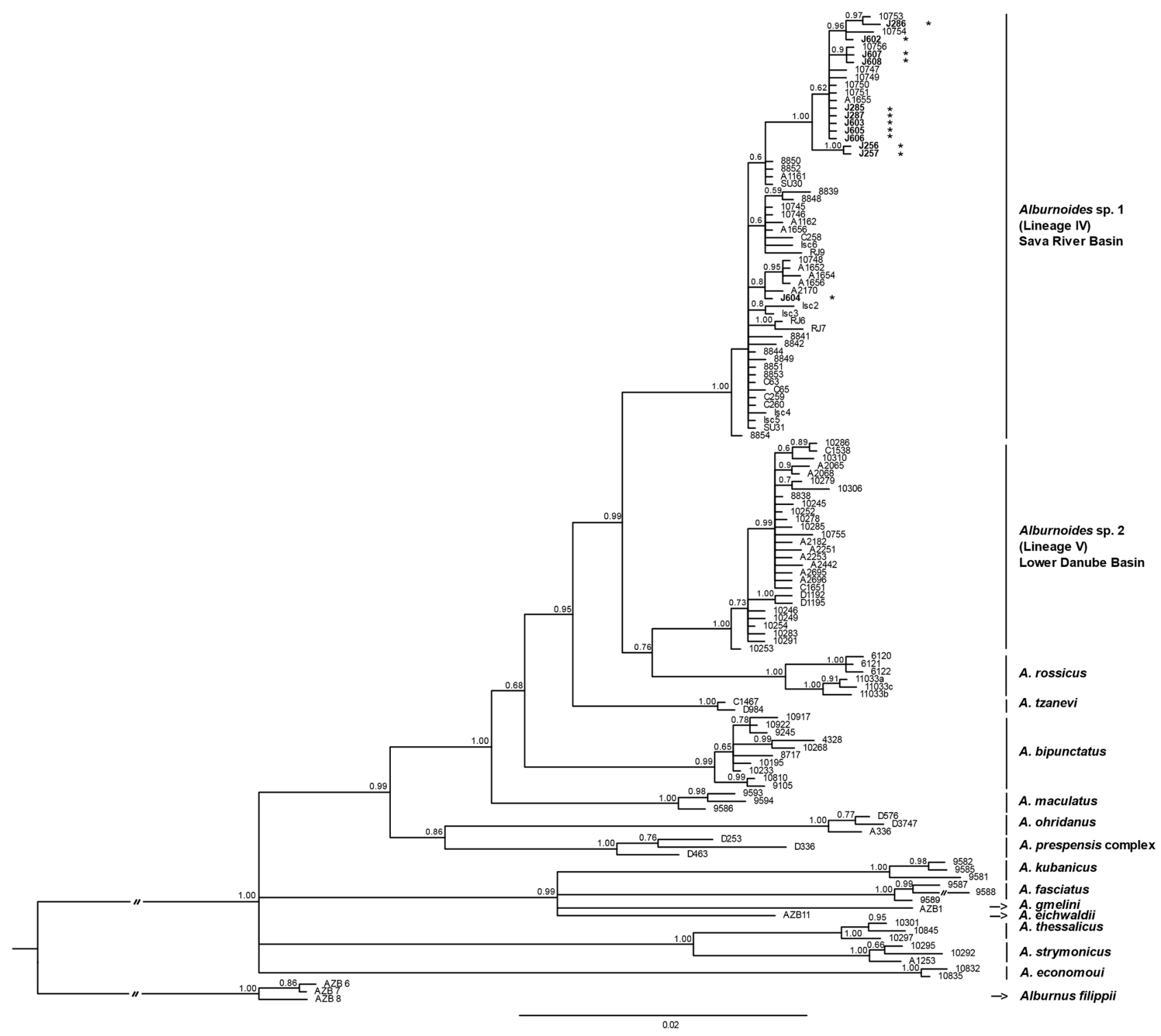

Fig. 2. Phylogenetic tree of cytochrome b sequences of Alburnoides spp. based on Bayesian inference method. Samples from the Neretva river basin are indicated by asterisk. Numbers on the branches indicate the posterior probability support. Lineages named according to Stierandová et al. (2016).

cytochrome $b$ of the available European species/clades of Alburnoides (Stierandová et al., 2016) were included in the analyses. Alburnus filippii was used as outgroup. New sequences were deposited in GenBank under the accession numbers MH656906-MH656910. The details about the samples used for the molecular data analyses are included in Table S3.

The best fitting model of nucleotide substitution was estimated using JModelTest 0.1.1 (Posada, 2008). The $\mathrm{GTR}+\mathrm{G}$ model was selected using Akaike information criterion. A Bayesian analysis was conducted using MrBayes v. 3.1.2 (Huelsenbeck and Ronquist, 2001). Two runs, each consisting of four Monte Carlo Markov Chains, were run simultaneously for 10000000 generations with sampling trees every 100 generations. The first $25 \%$ of trees were discarded as burn-in and the remaining trees were used to construct a $50 \%$ majority-rule consensus tree. The posterior probabilities indicate the branch supports in the final tree.

A detailed reconstruction of relationships of the haplotypes of Alburnoides population from the Neretva river basin and other most closely related populations was performed by a statistical parsimony method under a 95\% connection limit, using TCS v. 1.21 (Clement et al., 2000).

\section{Results}

The size of the 18 collected specimens ranged from $26 \mathrm{~mm}$ to $91 \mathrm{~mm}$ standard length. Based on the molecular analyses of cytochrome $b$ gene of 12 specimens (Fig. 2), the population from the Neretva river basin belongs to Alburnoides sp. 1 sensu Stierandová et al. (2016) inhabiting the Sava river basin (Danube river basin, Black Sea slope). Some of the observed 


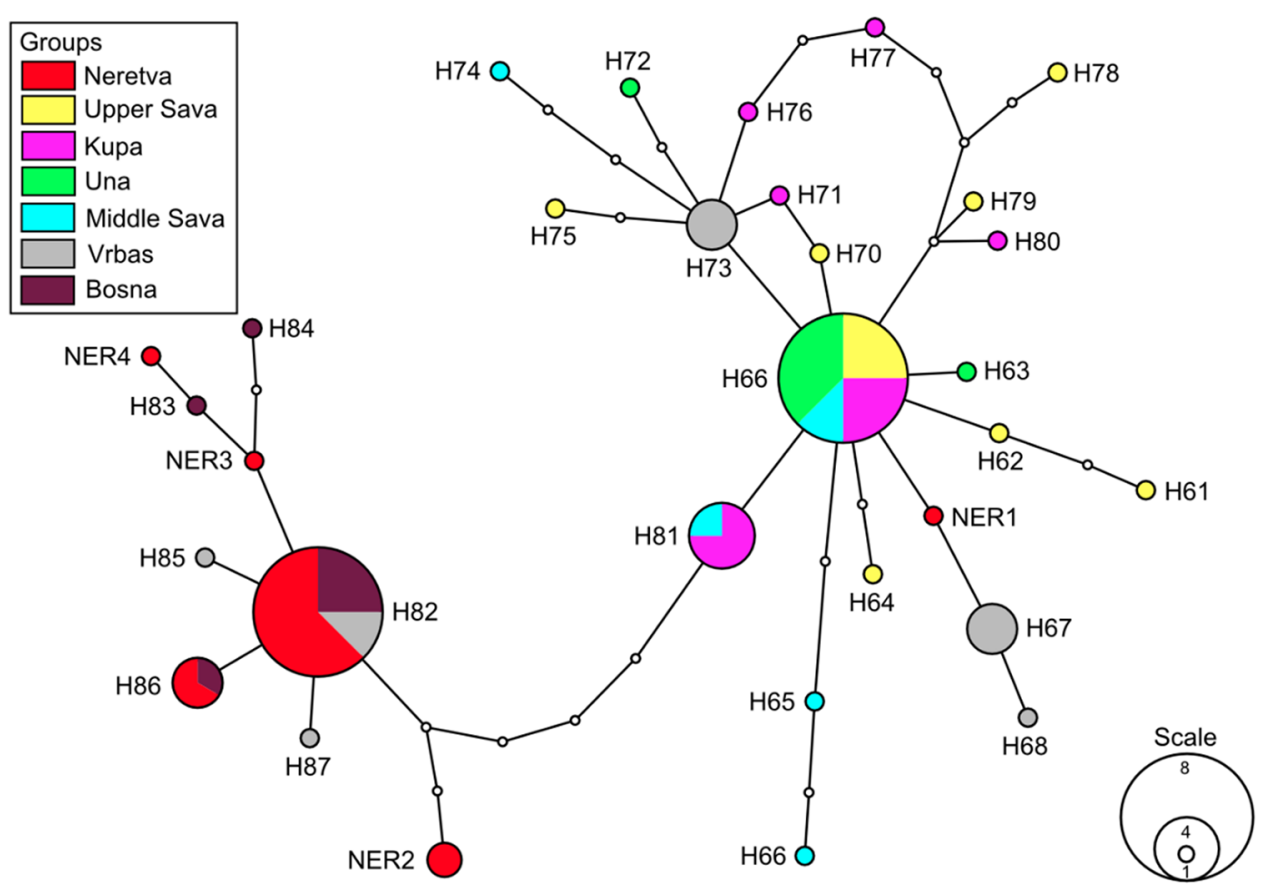

Fig. 3. Haplotype network of cytochrome b sequences of Alburnoides sp. 1 sensu Stierandová et al. (2016) constructed by statistical parsimony method under a 95\% connection limit. Haplotype codes correspond to information on samples in Table S3.

haplotypes are identical to already published ones in Stierandová et al. (2016), several are new (NER1-4, Fig. 3), but all of them are either identical to (including the most frequent one, H82) or greatly similar to the ones belonging to the specimens originating from the Vrbas and the Bosna river basins (Fig. 3); both rivers are tributaries of the Sava river (see Fig. 1).

\section{Discussion}

The knowledge on the diversity of spirlin (Alburnoides) in Europe was updated only very recently, mostly owning to analyses of DNA sequence data (Geiger et al., 2014; Stierandová et al., 2016). One decade ago only three species of spirlin were recognised (Kottelat and Freyhof, 2007). Later, three new species were described, two of which from Albania (Bogutskaya et al., 2010) and one from Greece (Barbieri et al., 2017). However, the molecular data revealed a presence of altogether 17 evolutionary lineages of Alburnoides in Europe (Stierandová et al., 2016). Eleven of these were possible to assign to the previously described taxa (Levin et al., 2016; Stierandová et al., 2016; Barbieri et al., 2017), two are considered to represent yet undescribed species, while the Alburnoides prespensis complex requires further taxonomic clarification (Stierandová et al., 2016).

No Alburnoides species has been known from the Neretva river basin (Glamuzina et al., 2013). Several species of the genus occur in adjacent regions. In the Ohrid-DrinSkadar basin and some other Albanian rivers, A. ohridanus is present (Stierandová et al., 2016). Further to the south, the Albanian basins host A. prespensis complex (A. prespensis, A. fangfangae and A. devolli) (Kottelat and Freyhof, 2007;
Bogutskaya et al., 2010; Stierandová et al., 2016). Geographically very close Danubian basin rivers from Bosnia and Herzegovina and Croatia, all tributaries of the Sava river, are inhabited by Alburnoides sp. 1 sensu Stierandová et al. (2016), whereas Danubian rivers located more easterly (Serbia, Bulgaria and Romania) are inhabited by Alburnoides sp. 2 sensu Stierandová et al. (2016).

We used a molecular approach to identify the newly recorded Alburnoides population from the Neretva river. Comprehensive comparative dataset is available for the mitochondrial marker cytochrome b for the European Alburnoides (Stierandová et al., 2016; Barbieri et al., 2017). Our analysis identified the population from the Neretva river as Alburnoides sp. 1 (Fig. 2). This still undescribed species inhabits the Sava river basin, which belongs to the Danube basin. It was reported, based on molecular data, from Slovenia, Croatia, Bosnia and Herzegovina and Serbia (Stierandová et al., 2016).

The ichthyofauna of the Neretva river basin is very specific, comprising many species endemic only to this basin. Only two species are considered to be shared with the adjacent rivers belonging to the Danube river basin. Molecular data provided an evidence on the conspecificity of Phoxinus from the Neretva river and some karstic basins connected underground to it, with the populations from the Danubian rivers (Palandačić et al., 2015). The other case is Cottus gobio; however, the relationships of populations of Cottus from the Neretva River and the Danube basin are awaiting clarification. Both Phoxinus and Cottus are considered native to the Neretva river basin (Karaman, 1928; Glamuzina et al., 2013) and were known from here since the first report about the ichthyofauna of the Neretva river basin (Karaman, 1928), unlike Alburnoides, which has never been recorded before from this river (see the discussion below). No contemporary connection 
between the Neretva river basin and Sava tributaries is known, neither surface nor underground (Palandačić et al., 2015, for details see their Supplementary material), thus natural dispersion of Alburnoides from the Sava to the Neretva river basin is unlikely.

Although it is currently abundant, there are no previous records of Alburnoides from the Neretva river basin in any of the numerous faunistic papers (i.e. Karaman, 1928; Kosorić and Vuković, 1966; Kosorić, 1974, 1977, 1978; Vuković, 1977; Kosorić et al., 1989; Šanda et al., 2008b; Glamuzina et al., 2013). This indicates that it is an introduced species. There are no data on the possible time of introduction, but as it was not mentioned by Glamuzina et al. (2013, 2017), it is presumably a case of rather recent introduction. The cytochrome $b$ haplotypes of the specimens from the Neretva river basin are identical or very similar to those from the Vrbas and Bosna river basins in Bosnia and Herzegovina (Fig. 3). This fact suggests the introduction from the nearby located area of the Danube river basin, most probably directly within the country. Both juveniles and adults were present, and the species is quite common at both places from which we have obtained samples, thus we consider the population to be well established.

Alburnoides sp. is the $32^{\text {nd }}$ alien species recorded in the Neretva river basin (see Tab. S2) (Glamuzina et al., 2013, 2017; Dulčić et al., 2017; Tutman et al., 2017b; Šukalo et al., 2018). Although not all alien species adapted successfully (Glamuzina et al., 2017), the presence of such a high number of alien species, which approaches the number of native freshwater species ever recorded in the basin (34-see Tab. S1) and almost doubles the number of endemic species (17-see Tab. S1), is alarming. Very high proportions of the alien versus native species were observed also in other rivers of the Adriatic Sea slope (Jelić et al., 2016). A high proportion of the alien species in the Neretva river basin had been most probably translocated from the geographically very closely located Danube basin (Black Sea slope) - 14 species (see Tab. S2), which is almost a half of the total number of the introduced species in this river basin. Translocations were also documented in other Mediterranean countries, such as Greece or Italy, and even concern several endemic species (Bianco and Ketmaier, 2001; Koutsikos et al., 2012; Bianco, 2014; Barbieri et al., 2015). In the case of the Neretva river basin, translocations can be particularly dangerous because ecologically and morphologically similar species of the same genera inhabit both the Neretva and the Danube basins (e.g. Alburnus, Chondrostoma, Squalius, Rutilus, Scardinius, etc.) and can replace the native species. As a deterrent example, extinction of the native Protochondostoma genei in the Soča river in Slovenia was observed after the introduction of Chondrostoma nasus from the Danube basin (Povž, 1995).

We assume an important negative role of the sport fishery management in the spreading of non-native species in the Neretva river basin, as a result of intentional introductions of commercially important species (like Cyprinus carpio, Sander lucioperca, etc.), which are obviously accompanied by unintentional introductions of other, commercially unimportant, species (Gymnocephalus cernuus, Pseudorasbora parva, etc.) (Glamuzina et al., 2017). Alburnoides sp., a species without any economic importance, was probably introduced unintentionally or as a bait fish.
The native fish assemblage of the Neretva river basin is undoubtfully threatened by introductions of alien fish species. It is indispensable to raise public awareness especially among the local fishermen to prevent further increase of the number of the alien fish species.

\section{Supplementary Material}

Table S1 List of native fish species recorded from the Neretva river basin (including the karstic fields) based on the published data.

Table S2. List of introduced fish species recorded from the Neretva river basin (including karstic fields) based on the published data.

Table S3 List of samples and sequences used in the study. Information about the lineage according to Stierandová et al. (2016), locality, coordinates, haplotype, GenBank accession number and source included.

The Supplementary Material is available at https://www. kmae-journal.org/10.1051/kmae/2019007/olm.

Acknowledgements. We are highly grateful to Sanid Džino from Jablanica for collection of the Alburnoides specimens, and Ivan Bogut for big help in organisation of the work in Bosnia and Herzegovina. This work was supported by the Ministry of Culture of the Czech Republic (DKRVO2019-2023/6.V.a, National Museum, 00023272). Jasna Vukić was supported by the institutional resources of the Ministry of Education, Youth and Sports of the Czech Republic.

\section{References}

Barbieri R, Zogaris S, Kalogianni E, Stoumboudi M, Chatzinikolaou Y, Giakoumi S, Kapakos Y, Kommatas D, Koutsikos N, Tachos V, Vardakas L, Economou AN. 2015. Freshwater Fishes and Lampreys of Greece: An Annotated Checklist. Monographs on Marine Sciences No. 8. Athens, Greece: Hellenic Centre for Marine Research, $136 \mathrm{p}$.

Barbieri R, Vukić J, Šanda R, Kapakos Y, Zogaris S. 2017. Alburnoides economoui, a new species of spirlin from Central Greece and redescription of Alburnoides thessalicus (Actinopterygii, Cyprinidae). Biologia 72: 1075-1088.

Bianco PG. 2014. An update on the status of native and exotic freshwater fishes of Italy. J Appl Ichthyol 30: 62-77.

Bianco PG, Ketmaier V. 2001. Anthropogenic changes in the freshwater fish fauna of Italy, with reference to the central region and Barbus graellsii, a newly established alien species of Iberian origin. J Fish Biol 59: 190-208.

Bogutskaya NG, Zupančič P. 2003. Phoxinellus pseudalepidotus (Teleostei: Cyprinidae), a new species from the Neretva basin with an overview of the morphology of Phoxinellus species of Croatia and Bosnia-Herzegovina. Ichthyol Explor Freshwaters 14: 369-383.

Bogutskaya NG, Zupančič P, Naseka AM. 2010. Two new species of freshwater fishes of the genus Alburnoides, A. fangfangae and $A$. devolli (Actinopterygii: Cyprinidae), from the Adriatic Sea basin in Albania. Proc Zool Inst RAS 314: 448-468.

Bogutskaya N, Zupančič P, Bogut I, Naseka AM. 2012. Two new freshwater fish species of the genus Telestes (Actinopterygii, Cyprinidae) from karst poljes in Eastern Herzegovina and 
Dubrovnik littoral (Bosnia and Herzegovina and Croatia). ZooKeys 180: 53-80.

Buj I, Vukić J, Šanda R, Perea S, Ćaleta M, Marčić Z, Bogut I, Povž M, Mrakovčić M. 2010. Morphological comparison of bleaks (Alburnus, Cyprinidae) from the Adriatic Basin with the description of a new species. Folia Zool 59: 129-141.

Buj I, Šanda R, Marčić Z, Ćaleta M, Mrakovčić M. 2014. Combining morphology and genetics in resolving taxonomy - a systematic revision of spined loaches (Genus Cobitis; Cypriniformes, Actinopterygii) in the Adriatic watershed. PLoS ONE 9: e99833.

Clement M, Posada D, Crandall KA. 2000. TCS: a computer program to estimate gene genealogies. Mol Ecol 9: 1657-1659.

Dulčić J, Dragičević B, Ugarković P, Tutman P. 2017. The largemouth black bass (Micropterus salmoides): first record in the Neretva River delta, Adriatic drainage system of Croatia. Cybium 41: 77-78.

Geiger MF, Herder F, Monaghan MT, Almada V, Barbieri R, Bariche M, Berrebi P, Bohlen J, Casal-Lopez M, Delmastro GB, Denys GPJ, Dettai A, Doadrio I, Kalogianni E, Kärst H, Kottelat M, Kovačić M, Laporte M, Lorenzoni M, Marčić Z, Özulug M, Perdices A, Perea S, Persat H, Porcelotti S, Puzzi C, Robalo J, Šanda R, Schneider M, Šlechtová V, Stumboudi M, Walter S, Freyhof J. 2014. Spatial heterogeneity in the Mediterranean Biodiversity Hotspot affects barcoding accuracy of its freshwater fishes. Mol Ecol Resour 14: 1210-1221.

Glamuzina B, Pavličević J, Tutman P, Glamuzina L, Bogut I, Dulčić J. 2013. Ribe Neretve. Udruga CEAV, Mostar; Modrozelena-Zadruga branitelja, Metković, $263 \mathrm{p}$.

Glamuzina B, Tutman P, Nikolić V, Vidović Z, Pavličević J, Vilizzi L, Copp GH, Simonović P. 2017. Comparison of taxon-specific and taxon-generic risk screening tools to identify potentially invasive non-native fishes in the River Neretva catchment (Bosnia and Herzegovina and Croatia). River Res Appl 33: 670-679.

Huelsenbeck JP, Ronquist F. 2001. MRBAYES: Bayesian inference of phylogenetic trees. Bioinformatics 17: 754-755.

Jelić D, Špelić I, Žutinić P. 2016. Introduced species community overdominates endemic ichthyofauna of high Lika plateau (central Croatia) over a 100 year period. Acta Zool Acad Sci Hung 62: 191-216.

Karaman S. 1928. Prilozi ihtiologiji Jugoslavije I. Glasnik Skopskog Naučnog Društva 6: 147-176.

Kosorić D. 1974. Ribe rijeke Rame. Ichthyologia 6: 69-78.

Kosorić D. 1977. Populacije riba srednje Neretve, sa projekcijom razvojnih mogućnosti poslije izgradnje vodenih akumulacija. Ichthyologia 9: 121-129.

Kosorić D. 1978. Sastav populacije riba Hutova blata. Godišnjak Biološkog Instituta Univerziteta u Sarajevu 31: 69-81.

Kosorić D, Vuković T. 1966. Ribe rijeke Bune. Glasnik Zemaljskog muzeja Bosne i Hercegovine u Sarajevu. Prirodne nauke 5: 179-190.

Kosorić D, Vuković T, Guzina N, Kapetanović N, Mikavica D. 1989. Ihtiofauna rijeke Neretve i njene promjene posljedično izgradnji hidroelektrana, in Zbornik radova - Savjetovanje o ribarstvu na hidroakumulacijama, SOUR APRO Hercegovina, Mostar; Radna organizacija Ribogajilište, Blagaj; RO Hidroelektrane na Neretvi, Jablanica; OOUR Institut za studijsko-razvojne poslove, Mostar, pp. $133-138$.
Kottelat M, Freyhof J. 2007. Handbook of European freshwater fishes. Kottelat, Cornol, Switzerland and Freyhof, Berlin, Germany, $646 \mathrm{p}$.

Koutsikos N, Zogaris S, Vardakas L, Tachos V, Kalogianni E, Šanda R, Chatzinikolaou Y, Giakoumi S, Economidis PS, Economou AN. 2012. Recent contributions to the distribution of the freshwater ichthyofauna in Greece. Medit Mar Sci 13: 268-277.

Kovačić M. 2005. A new species of Knipowitschia (Gobiidae) from Dalmatia, Croatia. Cybium 29: 275-280.

Levin BA, Simonov E, Matveyev MP, Artaev ON, Mustafayev NJ, Pashkov AN, Roubenyan HR. 2016. DNA barcoding of the fishes of the genus Alburnoides (Actinopterygii, Cyprinidae) from Caucasus. Mitochondrial DNA Part A 27: 1-7.

Marr SM, Olden JD, Leprieur F, Arismendi I, Ćaleta M, Morgan DL, Nocita A, Šanda R, Tarkan AS, García-Berthou E. 2013. A global assessment of freshwater fish introductions in Mediterraneanclimate regions. Hydrobiologia 719: 317-329.

Palandačić A, Bravničar J, Zupančič P, Šanda R, Snoj A. 2015. Molecular data suggest a multispecies complex of Phoxinus (Cyprinidae) in the Western Balkan Peninsula. Mol Phylogenet Evol 92: 118-123.

Posada D. 2008. jModelTest: phylogenetic model averaging. Mol Biol Evol 25: 1253-1256.

Povž M. 1995. Chondrostoma nasus nasus in the waters of Slovenia. Folia Zool 44: 9-15.

Šanda R, Vukić J, Choleva L, Kř́žek J, Šedivá A, Shumka S, Wilson IF. 2008a. Distribution of loach fishes (Cobitidae, Nemacheilidae) in Albania, with genetic analysis of populations of Cobitis ohridana. Folia Zool 57: 42-50.

Šanda R, Bogut I, Doadrio I, Kohout J, Perdices A, Perea S, Šedivá A, Vukić J. 2008b. Distribution and relationships of spined loaches (Cobitidae) in the Neretva River basin in Bosnia and Herzegovina. Folia Zool 57: 20-25.

Schönhuth S, Vukić J, Šanda R, Yang L, Mayden RL. 2018. Phylogenetic relationships and classification of the Holarctic family Leuciscidae (Cypriniformes: Cyprinoidei). Mol Phylogenet Evol 127: 781-799.

Stierandová S, Vukić J, Vasil'eva ED, Zogaris S, Shumka S, Halačka K, Vetešník L, Švátora M, Nowak M, Stefanov T, Koščo J, Mendel J. 2016. A multilocus assessment of nuclear and mitochondrial sequence data elucidates phylogenetic relationships among European spirlins (Alburnoides, Cyprinidae). Mol Phylogenet Evol 94: 479-491.

Šukalo G, Dmitrović D, Golub D. 2018. First record of the weatherfish Misgurnus fossilis (Linnaeus, 1758) from the Adriatic Sea catchment area in Bosnia and Herzegovina. Ecol Montenegrina 18: $126-128$.

Tutman P, Freyhof J, Dulčić J, Glamuzina B, Geiger M. 2017a. Lampetra soljani, a new brook lamprey from the southern Adriatic Sea basin (Petromyzontiformes: Petromyzontidae). Zootaxa 4273: 531-548.

Tutman P, Buj I, Ćaleta M, Hamzić A, Korjenić E, Adrović A, Glamuzina B. 2017b. Status and distribution of spined loaches (Cobitidae) and stone loaches (Nemacheilidae) in Bosnia and Herzegovina. Folia Zool 66: 211-226.

Vuković T. 1977. Ribe Bosne i Hercegovine. Sarajevo: IGKRO Svjetlost, 206 p.

Cite this article as: Vukić J, Eliášová K, Marić D, Šanda R. 2019. Occurrence of alien spirlin (Alburnoides sp.) in the Neretva river basin. Knowl. Manag. Aquat. Ecosyst., 420, 15. 